\title{
Thermal Performance of Tropical Atrium
}

\author{
Mohammad Baharvand ${ }^{1}$, Mohd Hamdan Bin Ahmad ${ }^{2}$, Tabassom Safikhani ${ }^{3},{ }^{1-3}$ Universiti Teknologi Malaysia, \\ Sayyed Mohammad Mahdi Mirmomtaz,${ }^{4}$ Islamic Azad University of Najaf Abad
}

\begin{abstract}
Atrium is a popular architectural feature utilized widely by building designers and owners to bring various benefits such as adequate daylight, circulation spaces and surfaces for landscape applications. But atrium problems in tropical climates such as excessive daylight, glare and high temperature, which lead to increase building energy demand, have been reported. To avoid and reduce these unpleasant features, a side-lit atrium has been suggested. Although researchers proposed side-lit atrium to prevent common problems of atria, the lack of precedent research on this issue compels these authors to study atrium performance in hot and humid climate. So the research aims to examine two different atrium roof form types in terms of temperature and ventilation impacts in hot and humid climate of Malaysia using DesignBuilder as a simulation program. The results indicate lower temperature of side-lit model with better airflow pattern in comparison with top-lit model while the top-lit model provides higher air velocity at the air inlet and outlet.
\end{abstract}

Keywords - atrium; simulation; DesignBuilder; side/top-lit.

\section{INTRODUCTION}

Atrium is defined as a space added to the buildings with at least one transparent facade which commonly is high [1]. It is an architectural feature in different building types such as office buildings, shopping malls and educational spaces. Designing and controlling the thermal conditions of the atria are not easy due to numerous characteristics of the space such as walls with large areas, small usage zone ratio, high ceiling and so on [2].

Atrium provides an internal space and protects it against outdoor unfavorable weather conditions. The internal area can be used as a circulation path above the ground level. This feature is common in commercial buildings requiring a wide path for walking as well as office buildings to provide further usable areas. Advantages of atrium are not limited to this feature, and its environmental benefits encourage designers and owners to add it to their buildings. Providing adequate solar gain and daylight as well as improving thermal comfort features have been mentioned are some of the benefits of atrium[3]. The environmental features of atria strongly depend on parameters which are the result of climate conditions. Solar gain and access to daylight are two main benefits of atria in cold climates. In cold weather conditions and during sunny days, an atrium is a pleasant sunspace which also provides a buffer zone between undesirable outdoor conditions and indoor zones [4].

The scenario of atrium environmental benefits changes when it is integrated in the building under hot climate conditions such as hot and humid climate of Malaysia. Environmental problems of atrium reduce the attractiveness of this architectural feature [5]. The top glazed surfaces allow deeper daylight to bring the pleasantinternal spaces while reducing proper conditions for achieving thermal comfort [6]. Also in tropical climates, excessive solar radiation through glazed surfaces may worsen internal thermal conditions especially during working hours [7]. The overheating issue is not actually fully apparent until the building is completed and its occupants use the space. Unfortunately, negative aspects and effects of atrium are often neglected throughout the design process, and increasingly such atriums are integrated into buildings only for aesthetic reasons. Recent research shows the number of glazed envelopes have expanded even in Southern Asia countries with hot and humid climate [3] and Malaysia as well [8].

The American Society of Heating, Refrigerating and Air Conditioning Engineers (ASHRAE) mentioned the uncomfortable condition of glass box buildings when used regardless of other effective parameters [9]. Also, atrium problems in hot climates such as excessive daylight, glare and high temperature lead to increase energy demand of buildings [10]. Among these items, overheating is the major problem of atria in hot climates contributing to thermal comfort reduction.

Natural ventilation of the atrium can decrease negative impacts of overheating in internal spaces. In naturally ventilated buildings, the heat at the top of the atrium exits by the wind driving force and stack effect. Indeed, the stack effect lifts air from the lower part of the atrium to the top section and removes it through the openings located at the atrium roof or sides. Although the hot air at the top of the atrium improves upward airflow, at the same time it causes unpleasant thermal conditions for occupants of the top floors. The major reason for overheating is the excessive solar radiation penetrating into the atrium through the glazed surfaces. Thus, controlling the solar radiation is an essential parameter which increasingly can be done by attaching shading devices and evaporation cooling systems [11]. The impacts of these approaches are remarkable when they are taken into account during the design process. Knowing the types and thermal performance of atrium are essential for designers to prevent unintentional problems due to excessive solar radiation and overheating.

Atria are categorized based on the number of sides surrounded by building mass [12]. Hung and Chow [13] explained the typology of atria in an architectural viewpoint, including environmental and economic aspects. Top-lit atrium and side-lit atrium were also mentioned according to the roof shape and daylight openings. Top-lit atrium in Malaysia is an imported architectural feature, which is the result of designers' tendencies while side-lit atrium is the traditional response to excessive daylight [3]. In addition, to prevent and control the 
unpleasant effects of atrium overheating, researchers proposed side-lit atrium instead of top-lit atrium in a tropical climate. Ahmad, M. H. and Rasdi, M. T. H. M.[10] explained different atrium forms and examined atrium in some selected shopping malls in Malaysia. They numbered advantages and disadvantages of the side-lit atrium and suggested it for tropical climate. Abdullah and Wang [3] examined different atrium roof forms in a tropical climate. They studied the atrium roof form as a critical parameter in terms of thermal comfort and running cost.

The bulk of precedent researches on the performance of top-lit and side-lit atrium lead this research to evaluate them in terms of airflow pattern and temperature distribution in hot and humid climate of Malaysia. Indeed, the research aims to compare these atrium roof forms to find out their performance under naturally ventilated conditions. Knowing the different aspects of atrium and clarifying their thermal performance assist designers in the process of designing to make a proper decision based on the project conditions.

\section{METHOD AND KEY PARAMETERS}

In this paper, two atrium roof forms are examined in naturally ventilated conditions utilizing simulation with Computational Fluid Dynamic (CFD). Different methods have been proposed to study natural ventilation and air movement in buildings such as empirical, small-scale experimental, full-scale experimental, multizone, Zonal and CFD models [14]. Among these, CFD is one of the most popular methods due to lower cost and controllable conditions in comparison with other approaches. Although CFD was introduced for industrials proposes, it now becomes a common method to evaluate ventilation and environment of buildings [15]. DesignBuilder is used in this research as a simulation program for calculating atrium performance.

\section{SOFTWARE VERIFICATION AND VALIDATION}

The applications of CFD models are not limited to ventilation aims in buildings, and it is known as a method to predict different parameters of thermal comfort, indoor air quality, fire safety, HVAC system performance and more in different types of buildings [14]. CFD modeling is employed in the design process and provides accurate and cost effective results $[16 ; 17 ; 18 ; 19]$. It is a useful tool for engineers and designers to calculate the inside and outside conditions of buildings, and acceptable results have been achieved in terms of energy usage and airflow based on CFD modeling [20]. Although CFD methods bring various advantages, users and developers of this software come up against new issue by developing the computer simulation and CFD usage. They should know how they can rely on the simulation results. Verification and Validation $(\mathrm{V} \& \mathrm{~V})$ are the primary methods in response to this issue [21].

Numerous parameters affect the accuracy of the CFD results for natural ventilation studies such as user's knowledge of fluid dynamics and experience with skill for using numerical techniques. However the major parameter with critical impacts is the appropriate selection of CFD approach and turbulence model [22]. The selected software for the research is DesignBuilder version 3.1.0.080 using EnergyPlus 7.2 for simulation and standard k-e turbulent model for CFD. Zhai et al. [22] reviewed some of the most popular and useful turbulence models for indoor ventilation aims and also turbulence classification.

Among various turbulence models, the $\mathrm{k}-\varepsilon$ model family is the most popular turbulence model and has the largest number of variants [22]. Standard k- $\varepsilon, \mathrm{RNG} \mathrm{k- \varepsilon}$ and realizable k- $\varepsilon$ model are some of these family members. Chen [23] compared five different models to predict simple room indoor airflow, and he concluded that standard k- $\varepsilon$ and RNG k- $\varepsilon$ can predict best airflow patterns. Additionally, numerous researches used standard $\mathrm{k}-\varepsilon$ for various purposes $[24 ; 25 ; 26$; 27]. Some of these studies were especially considering indoor air quality, and they have showed that standard $\mathrm{k}-\varepsilon$ predicts indoor air distribution reasonably and well $[28 ; 24 ; 29 ; 30 ; 31$; $32 ; 33 ; 34]$.

On the other hand, EnergyPlus is the official building simulation program of the United States Department of Energy, promoted through the Building and Technology Program of the Energy Efficiency and Renewable Energy Office [35]. Crawley et al. [36] demonstrated EnergyPlus and compared it with previous programs in this field. $\mathrm{He}$ mentioned numerous advantages and benefits of EnergyPlus for building purposes. Numerous studies have used EnergyPlus in various fields $[37 ; 38 ; 39 ; 40 ; 41]$. Zhai et al. [42] employed EnergyPlus to calculate hybrid and natural ventilation in a building. Also, the validation of DesignBuilder for natural ventilation studies has been reported by the authors [43].

\section{MODEL SPECIFICATIONS}

As mentioned, this research studies two different atrium roof forms in the hot and humid climate of Malaysia. The first model is top-lit atrium; the second model is side-lit atrium. The following are the main characteristics of modeling and weather conditions taken from the Abdullah et al. [11] studied model.

- Building activity is defined as an office building with only natural ventilation for cooling aims.

- The building plan is rectangular with $30 \mathrm{~m}$ length in south and north and $21 \mathrm{~m}$ in west and east direction.

- The building includes three levels with $3.4 \mathrm{~m}$ height per each floor (Figure 1).

- The building includes 10 zones on the ground floor and 8 zones on the 1 st and 2 nd floors.

- The atrium plan is rectangular along the length of the building with a $21 \mathrm{~m} \times 9 \mathrm{~m}$ dimension.

- The width of circulation area around the atrium is $1.5 \mathrm{~m}$.

- The building is assumed to be in an excellent mode of infiltration.

- All simulations are run for the period from 18th to 23th of March.

- CFD calculations are run at 2pm on 21st of March. 
All zone doors and windows are closed and they are only ventilated through the vents. There are three types of opening allowing for airflow during simulation. Two west and east exterior doors (low level openings) and vents in the ground floor which are entirely open over calculation in both models and provide $10 \mathrm{~m}^{2}$ opening area for ventilation. Although models have different windows at the top of the atria, both of them provide the same opening areas for airflow which is $5 \mathrm{~m}^{2}$.

(a)

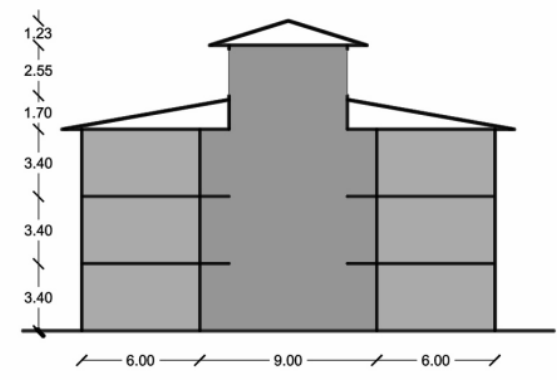

(b)

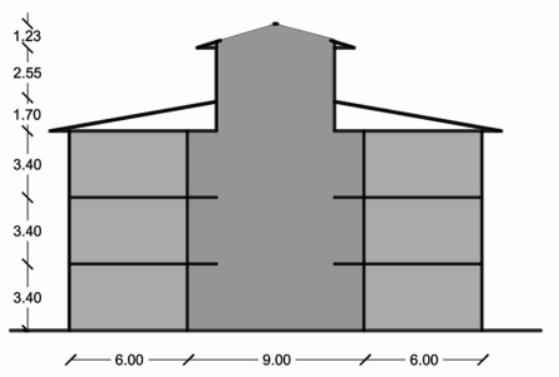

Fig. 1. (a) Side-Lit Atrium Section and (b) Top-Lit Atrium Section

The 2002 weather data of Subang, Kuala Lumpur is used for simulation. This data file includes temperature, wind velocity and direction, solar altitude, solar azimuth, atmospheric pressure, direct normal solar and diffuse horizontal solar data. Previous studies showed temperature has been increased in the city center while this growth is not significant in rural or suburban area $[44 ; 45]$, thus updated weather data would be needed for simulations. However, the modeled building is a low rise building, and it is assumed to be in a suburban area, so the weather data file is used without changes. 21st of March is chosen for CFD mentioned as the hottest design day in Malaysia [46; 47].

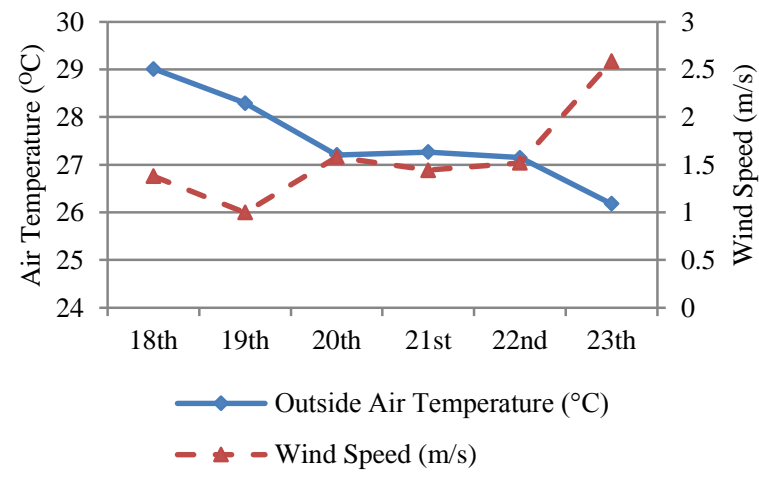

Fig. 2. Weather Data over the Simulations
Figure 2 indicates external wind velocity and air temperature employed for simulations from 18th to 23th of March. The external wind direction is unstable and its 160 , 117, 110, 183, 109 and 236 degree for 18th to 23th, respectively. Also, the CFD grid structure of these models included 301000 cells and 9 monitoring points defined within the atria and adjacent rooms.

\section{RESUlTS AND DisCUSSION}

As mentioned in the modeling section, two doors with $5 \mathrm{~m}^{2}$ area are the main air inlet in the ground floor level. The results of the simulation show higher airflow rate for top-lit model in comparison with side-lit model (tab I).

TABLE I.

Airflow IN (M³/S) THROUGH THE DOORS (LOW LEVEL OPENINGS)

\begin{tabular}{|l|l|l|l|l|l|l|}
\cline { 3 - 7 } \multicolumn{2}{c|}{} & $\begin{array}{l}18 \text { th } \\
\text { Mar }\end{array}$ & $\begin{array}{c}19 \text { th } \\
\text { Mar }\end{array}$ & $\begin{array}{c}\text { 20th } \\
\text { Mar }\end{array}$ & $\begin{array}{c}21 \text { st } \\
\text { Mar }\end{array}$ & $\begin{array}{c}\text { 22nd } \\
\text { Mar }\end{array}$ \\
\hline \multirow{2}{*}{$\begin{array}{l}\text { Top-lit } \\
\text { Model }\end{array}$} & West Door & 1.77 & 1.66 & 1.90 & 1.84 & 1.70 \\
\cline { 2 - 7 } & East Door & 1.53 & 1.64 & 1.65 & 1.60 & 1.64 \\
\hline $\begin{array}{l}\text { Side-lit } \\
\text { Model }\end{array}$ & West Door & 1.54 & 1.42 & 1.58 & 1.53 & 1.50 \\
\cline { 2 - 7 } & East Door & 1.22 & 1.40 & 1.15 & 1.20 & 1.33 \\
\hline
\end{tabular}

Based on Table 1, in the top-lit model increasingly "airflow in" (airflow from outside to the atrium) for the east door is more than $1.6 \mathrm{~m}^{3} / \mathrm{s}$ while it is between 1.15 to $1.40 \mathrm{~m}^{3} / \mathrm{s}$ in the side-lit model. Also, airflow rate for the west door in the toplit model shows a higher rate which is between $1.66 \mathrm{~m}^{3} / \mathrm{s}$ and $1.90 \mathrm{~m}^{3} / \mathrm{s}$. West door airflow for side-lit atrium is not more than $1.58 \mathrm{~m}^{3} / \mathrm{s}$. In both models the rate of "airflow out" (airflow from atrium to the outside) is not significant. These results show better performance of the low level openings in the top-lit model which is able to provide higher airflow rate.

The roof openings area in both models is $5 \mathrm{~m}^{2}$. Fresh air flows into the atria through the low level openings, then it flows up due to the temperature differences between top and bottom of the atria, and finally the warm and used air will exit through the roof openings. Hence in the top level openings there are high rates of "airflow out" and low rate of "air flow in". In the side-lit model, the bigger opening area of north and south windows and external wind direction contribute to higher levels of airflow for these openings in comparison with west and east openings.

Top openings airflow rate in the top-lit model shows the same results due to the similarity of opening area and conditions in both windows. In this case, the maximum airflow rate is $1.91 \mathrm{~m}^{3} / \mathrm{s}$, and the minimum rate is $1.73 \mathrm{~m}^{3} / \mathrm{s}$ in both north and south opening (Table II).

TABLE II.

NORTH/SOUTH TOP LEVEL OPENING AIRFLOW OUT (M³/S) IN TOP-LiT MODEL

\begin{tabular}{|l|c|c|c|c|c|}
\cline { 2 - 5 } \multicolumn{1}{c|}{} & $\begin{array}{r}\text { 18th } \\
\text { Mar }\end{array}$ & $\begin{array}{c}\text { 19th } \\
\text { Mar }\end{array}$ & $\begin{array}{c}\text { 20th } \\
\text { Mar }\end{array}$ & $\begin{array}{c}\text { 21st } \\
\text { Mar }\end{array}$ & $\begin{array}{c}\text { 22nd } \\
\text { Mar }\end{array}$ \\
\hline Airflow out $\left(\mathrm{m}^{3} / \mathrm{s}\right)$ & 1.73 & 1.76 & 1.91 & 1.87 & 1.84 \\
\hline
\end{tabular}


These amounts show significant changes in the side-lit model. In this model, the maximum rate of $1.13 \mathrm{~m}^{3} / \mathrm{s}$ and the minimum rate of $0.84 \mathrm{~m}^{3} / \mathrm{s}$ for north opening and maximum rate of $1.14 \mathrm{~m}^{3} / \mathrm{s}$ and the minimum rate of $0.96 \mathrm{~m}^{3} / \mathrm{s}$ for south opening are observed. Highest rate of the west opening is $0.45 \mathrm{~m}^{3} / \mathrm{s}$, and this rate for east opening is not more than $0.50 \mathrm{~m}^{3} / \mathrm{s}(\mathrm{tab} \mathrm{III})$.

TABLE III.

TOP LEVEl OPENING AiRflow OUT (M3/S) IN SidE-Lit MODEL

\begin{tabular}{|l|c|c|c|c|c|}
\cline { 2 - 6 } \multicolumn{1}{c|}{} & $\begin{array}{c}\text { 18th } \\
\text { Mar }\end{array}$ & $\begin{array}{c}\text { 19th } \\
\text { Mar }\end{array}$ & $\begin{array}{l}20 \text { th } \\
\text { Mar }\end{array}$ & $\begin{array}{c}21 \text { st } \\
\text { Mar }\end{array}$ & $\begin{array}{c}\text { 22nd } \\
\text { Mar }\end{array}$ \\
\hline North Opening & 1.06 & 1.03 & 0.99 & 0.84 & 1.13 \\
\hline South Opening & 1.00 & 1.04 & 1.01 & 1.14 & 0.96 \\
\hline West Opening & 0.36 & 0.45 & 0.41 & 0.44 & 0.44 \\
\hline East Opening & 0.44 & 0.45 & 0.49 & 0.50 & 0.48 \\
\hline
\end{tabular}

More effective suction of top-lit model causes higher airflow rate observed in both roof openings and ground floor doors. Indeed, higher amount of solar radiations gained by the roof form creates a more powerful stack effect and leads to enhancing atrium ventilation. Although smaller openings in the side-lit model show a lower airflow rate, the air velocity of these openings is higher than two large windows. Indeed these smaller high level openings increase air velocity.

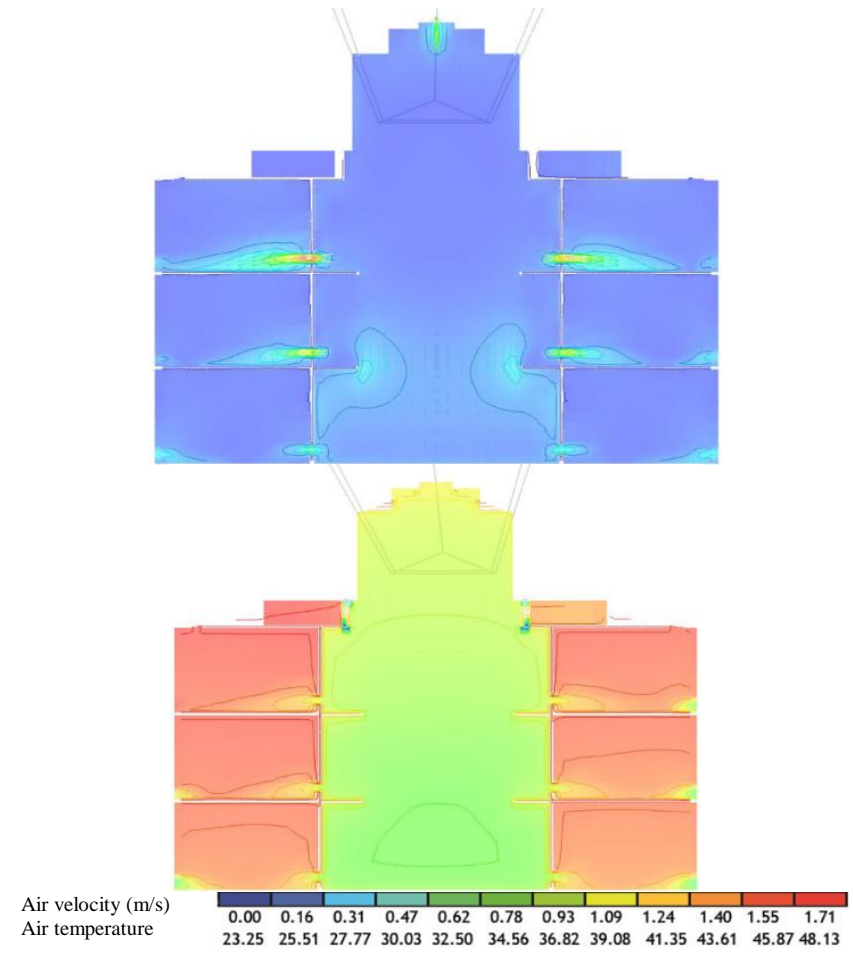

Fig. 3. Top-lit Atrium Crosswise Air Velocity (left) and Temperature (right) Distribution

Top-lit atrium in both top level and low level openings show higher airflow rate, but air movement and air contribution are different. Figure 3 shows the crosswise air velocity and temperature distribution in the top-lit model. It indicates air circulation is only created in the ground floor area of the atrium and in the lower half of the 1st floor while there is no considerable air movement at the top of the atrium. The air temperature changes are between $34^{\circ} \mathrm{C}$ to $39^{\circ} \mathrm{C}$, depending on the height of the atrium. The room temperature is higher than atrium which is around $48^{\circ} \mathrm{C}$, and there are no significant differences between rooms on the ground, 1st or 2nd floors (Figure 3).

Figure 4 shows the crosswise air velocity as well as temperature distribution in the side-lit atrium. Air movement in this model shows a slightly better distribution in comparison with other model while weak air circulation is created in the center of the atrium. In terms of temperature distribution, side-lit atrium temperature is limited between $30^{\circ} \mathrm{C}$ to $38^{\circ} \mathrm{C}$ while the majority of atrium space is around $33^{\circ} \mathrm{C}$, which is $6^{\circ} \mathrm{C}$ lower than top-lit model. More direct sun radiation in the top-lit atrium has a significant effect on the temperature differences of the two models and this higher atrium temperature affects adjacent zones as well.

The air pattern does not show significant changes in a lengthwise section of the top-lit model. Increasingly, top-lit atrium air movement is in the ground floor area, in front of vents connected to the atrium and at top level openings (Figure 5). Also, air temperature between $30^{\circ} \mathrm{C}$ to $39^{\circ} \mathrm{C}$ is observed in temperature distribution slice for top-lit atrium (Figure 6).

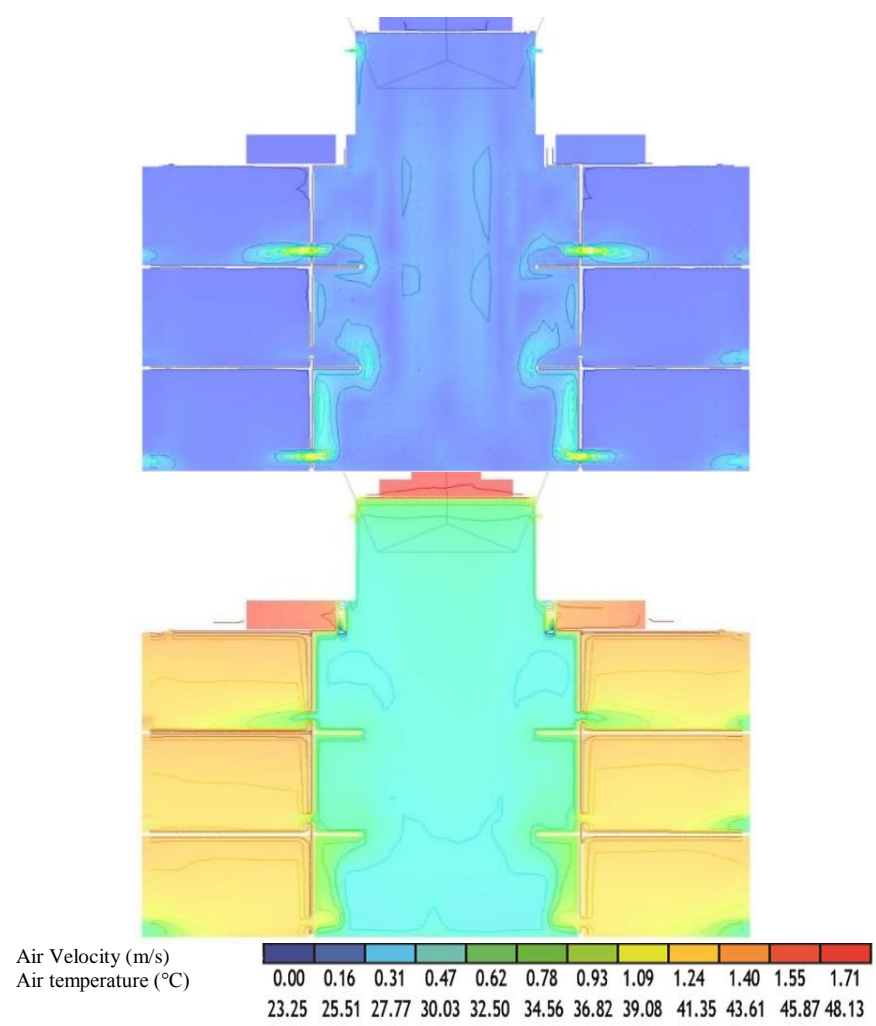

Fig. 4. Side-Lit Atrium Crosswise Air Velocity (left) and Temperature (right) Distribution

Lengthwise section of side-lit model shows significant changes in comparison with top-lit model. In top-lit model airflow is restricted to the ground floor, especially in front of doors and vents. This way, there is no acceptable air change and ventilation in the center of the atrium. But, side-lit model 
lengthwise section indicates air movement on the ground floor, near the surrounding walls, top level openings and slight movement in the middle (Figure 7). Air velocity near the corridors is about $1 \mathrm{~m} / \mathrm{s}$ which can be an acceptable rate for occupants. Another difference between the models is operation of the vents. Side-lit atrium does not show any airflow through vents between zones and atrium while the ventilation rate through the vents is considerable in the top-lit model. Same as the crosswise section, the total temperature of side-lit model is lower than top-lit model. More direct sunlight and higher solar radiation are the main reasons for these differences (Figure 8).

Air velocity and temperature plan sections of the models also show the lower temperature of the side-lit atrium and proper air distribution of this model in comparison with top-lit model. Also, these differences are observed in the zones adjacent to the atriums.

However, comparison of the heat transfer through the atrium glazing reveals better performance of the top-lit atrium in comparison with the side-lit model (Figure 9).

Since the simulation results of this section have minus values, they show the heat exiting from the atrium through the glazing. In order to compare, all minus values are converted to positive values.

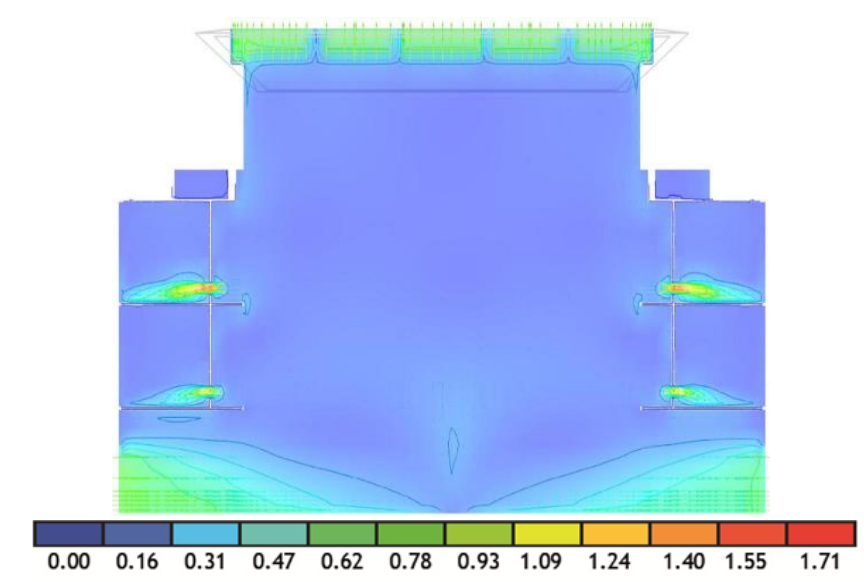

Air velocity $(\mathrm{m} / \mathrm{s})$

Fig. 5. Top-lit Atrium Length Wise Air Velocity

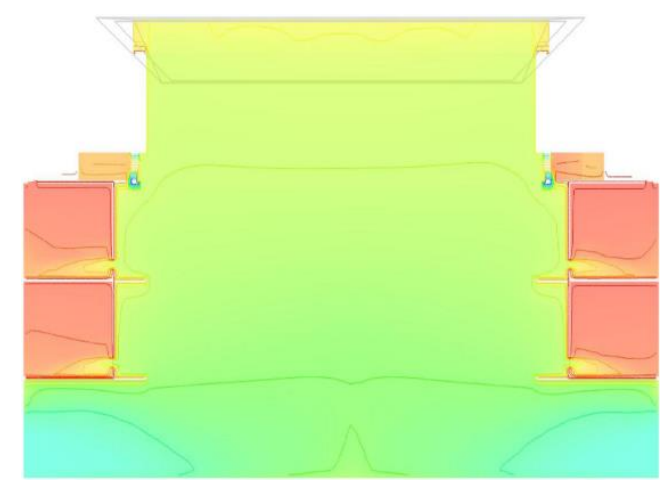

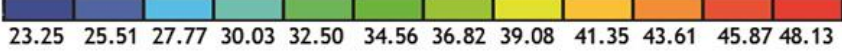

Air temperature (oC)

Fig. 6. Top-lit Atrium Length Wise Temperature Distribution Slice

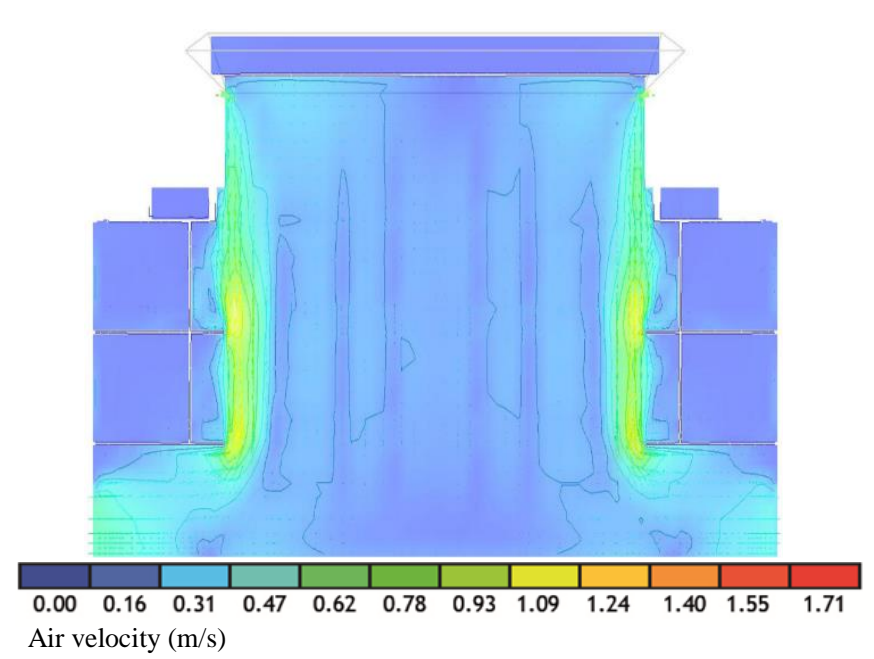

Fig. 7. Side-lit Atrium Length Wise Air Velocity Slice

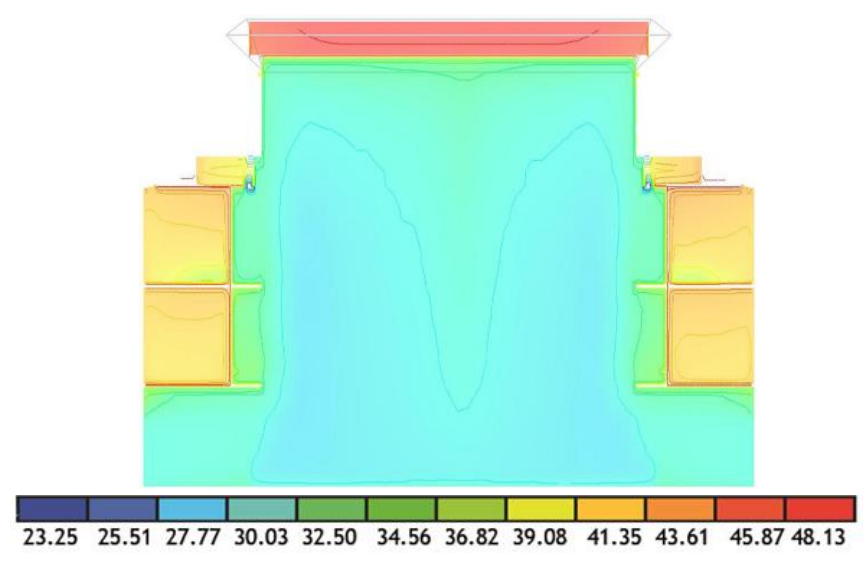

Air temperature $\left({ }^{\circ} \mathrm{C}\right)$

Fig. 8. Side-lit Atrium length Wise Temperature Distribution Slice

As Figure 9 indicates, top-lit atrium provides more proper conditions for heat loss. The maximum heat loss is achieved for 23th March while the external wind speed is increased to around $2.5 \mathrm{~m} / \mathrm{s}$. Despite this point, the top-lit model creates higher internal temperature and heat loss value cannot cover its higher temperature.

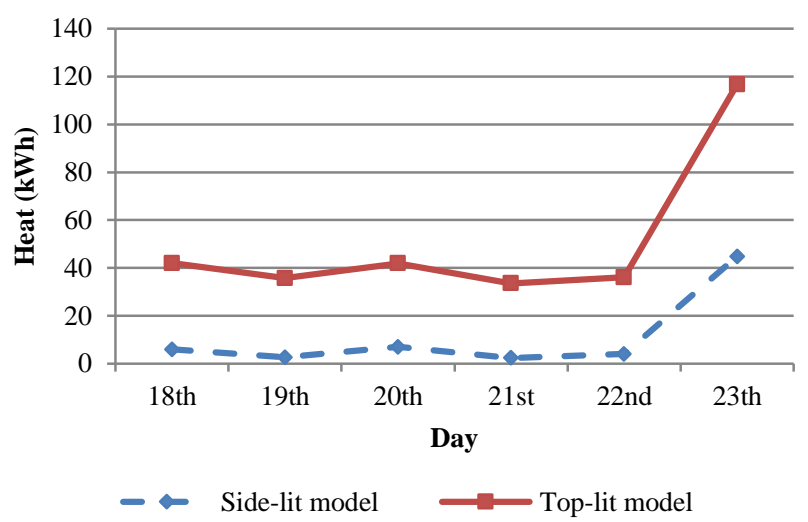

Fig. 9. Heat Loss through Atria Glazing 


\section{CONCLUSION}

This paper presents simulations with CFD results of two atrium roof type models in terms of ventilation rate and temperature distribution. Two buildings integrated with a central atrium are modeled under the hot and humid climate of Kuala Lumpur, Malaysia. All the parameters in both models are similar, and the differences are limited to the atrium roof form. The aims of the research are to find out the top-lit and side-lit atrium performance in terms of air temperature and airflow. This study indicates higher atrium air temperature tolerance in the top-lit model with a range of $36.82^{\circ} \mathrm{C}$ to $39.08^{\circ} \mathrm{C}$ while most of the atrium spaces in the side-lit atrium are $30^{\circ} \mathrm{C}$. These differences are also observed in corridors which are denser with occupants. Although in both models, the atrium temperatures are over the thermal conditions range of hot and humid climate, the low temperature of the side-lit atrium provides better conditions for occupants particularly in the atrium space. Top-lit model creates higher airflow in the atrium, but the air distribution of side-lit model is more effective especially around the corridors. The fresh air flowing into the atriums through the ground floor doors is closer to the corridors in the side-lit model, and it can provide higher air movement in this section. These results can be useful in decision making of architects and designers to choose a proper atrium roof form.

\section{ACKNOWLEDGMENTS}

The authors would like to acknowledge the Ministry of Higher Education and Universiti Teknologi Malaysia (UTM) at Johor Bahru for support and assistance via research grant (VOT02H14) and international doctoral fellowship (IDF). They would also like to thank the faculty of Built Environment and Institute Sultan Iskandar of Urban Habitat and Highrise for their support.

\section{REFERENCES}

1. Rundle, C. A.,Lightstone, M. F.,Oosthuizen, P. et al. Validation of computational fluid dynamics simulations for atria geometries. Building and Environment, 2011, 46 (7), p. 1343-1353.

2. Qin, R.,Yan, D.,Zhou, X. et al. Research on a dynamic simulation method of atrium thermal environment based on neural network. Building and Environment, 2012, 50 (0), p. 214-220.

3. Abdullah, A. H.,Wang, F. Design and low energy ventilation solutions for atria in the tropics. Sustainable Cities and Society, 2011, 2 (1), p. 8-28.

4. Hawkes, D.,Baker, N. Atria and conservatories. Architects' Journal, $1983,177 \mathrm{p}$.

5. Wang, F.,Abdullah, A. H. Investigating thermal conditions in a tropic atrium employing CFD and DTM techniques. International Journal of Low-Carbon Technologies, 2011, 6 (3), p. 171-186.

6. Douvlou, E.,Pitts, A. Glazed spaces in the Mediterranean climate: design of glazing and shading devices in atria. Architecture, City, Environment: Proceedings of PLEA, 2000, p. 292-293.

7. Pan, Y.,Li, Y.,Huang, Z. et al. Study on simulation methods of atrium building cooling load in hot and humid regions. Energy and Buildings, 2010, 42 (10), p. 1654-1660.

8. Yunus, J.,Ahmad, S. S.,Zain-Ahmed, A. Analysis of atrium's architectural aspects in office buildings under tropical sky conditions. In: International Conference on Science and Social Research (CSSR 2010), 5-7 Dec. 2010.

9. Harriman, L. G. The ASHRAE guide for buildings in hot and humid climates. American Society of Heating, Refrigerating, and AirConditioning Engineers, 2009. p.
10. Ahmad, M. H.,Rasdi, M. T. H. M. Design principles of atrium buildings for the tropics. Penerbit UTM, 2000. p.

11. Abdullah, A. H.,Meng, Q.,Zhao, L. et al. Field study on indoor thermal environment in an atrium in tropical climates. Building and Environment, 2009, 44 (2), p. 431-436.

12. Sharples, S.,Lash, D. Daylight in atrium buildings: A critical review. Architectural Science Review, 2007, 50 (4), p. 301-312.

13. Hung, W. Y.,Chow, W. K. A Review on Architectural Aspects of Atrium Buildings. Architectural Science Review, 2001, 44 (3), p. 285-295.

14. Chen, Q. Ventilation performance prediction for buildings: A method overview and recent applications. Building and Environment, 2009, 44 (4), p. 848-858.

15. Asfour, O. S.,Gadi, M. B. A comparison between CFD and Network models for predicting wind-driven ventilation in buildings. Building and Environment, 2007, 42 (12), p. 4079-4085.

16. Ji, Y.,Cook, M. J.,Hanby, V. CFD modelling of natural displacement ventilation in an enclosure connected to an atrium. Building and Environment, 2007, 42 (3), p. 1158-1172.

17. Laouadi, A.,Atif, M. R. Comparison between computed and field measured thermal parameters in an atrium building. Building and Environment, 1998, 34 (2), p. 129-138.

18. Tan, G.,Glicksman, L. R. Application of integrating multi-zone model with CFD simulation to natural ventilation prediction. Energy and Buildings, 2005, 37 (10), p. 1049-1057.

19. Wang, X.,Huang, C.,Cao, W. Mathematical modeling and experimental study on vertical temperature distribution of hybrid ventilation in an atrium building. Energy and Buildings, 2009, 41 (9), p. 907-914

20. Chien, C. H.,Lin, H. T.,Chou, J. H. et al. Buoyancy Ventilation Efficiency Analysis of a Conference Hall. Applied Mechanics and Materials, 2011, 71 p. 2442-2446.

21. Oberkampf, W. L.,Trucano, T. G. Verification and validation in computational fluid dynamics. Progress in Aerospace Sciences, 2002, 38 (3), p. 209-272.

22. Zhai, Z.,Zhang, Z.,Zhang, W. et al. Evaluation of various turbulence models in predicting airflow and turbulence in enclosed environments by CFD: Part 1 - Summary of prevalent turbulence models. HVAC and $R$ Research, 2007, 13 (6), p. 853-870.

23. Chen, Q. COMPARISON OF DIFFERENT k- $\varepsilon$ MODELS FOR INDOOR AIR FLOW COMPUTATIONS. Numerical Heat Transfer, Part B: Fundamentals, 1995, 28 (3), p. 353-369.

24. Cheung, J. O. P.,Liu, C.-H. CFD simulations of natural ventilation behaviour in high-rise buildings in regular and staggered arrangements at various spacings. Energy and Buildings, 2011, 43 (5), p. 1149-1158.

25. Norton, T.,Grant, J.,Fallon, R. et al. Optimising the ventilation configuration of naturally ventilated livestock buildings for improved indoor environmental homogeneity. Building and Environment, 2010, 45 (4), p. 983-995.

26. Teitel, M.,Ziskind, G.,Liran, O. et al. Effect of wind direction on greenhouse ventilation rate, airflow patterns and temperature distributions. Biosystems Engineering, 2008, 101 (3), p. 351-369.

27. Wang, L.,Wong, N. H. Coupled simulations for naturally ventilated residential buildings. Automation in Construction, 2008, 17 (4), p. 386398.

28. Bartzanas, T.,Boulard, T.,Kittas, C. Effect of Vent Arrangement on Windward Ventilation of a Tunnel Greenhouse. Biosystems Engineering, 2004, 88 (4), p. 479-490.

29. Gadgil, A. J.,Lobscheid, C.,Abadie, M. O. et al. Indoor pollutant mixing time in an isothermal closed room: An investigation using CFD. Atmospheric Environment, 2003, 37 (39-40), p. 5577-5586.

30. Mistriotis, A.,Arcidiacono, C.,Picuno, P. et al. Computational analysis of ventilation in greenhouses at zero- and low-wind-speeds. Agricultural and Forest Meteorology, 1997, 88 (1-4), p. 121-135.

31. Nahor, H. B.,Hoang, M. L.,Verboven, P. et al. CFD model of the airflow, heat and mass transfer in cool stores. International Journal of Refrigeration, 2005, 28 (3), p. 368-380.

32. Rouaud, O.,Havet, M. Computation of the airflow in a pilot scale clean room using $\mathrm{K}-\varepsilon$ turbulence models. International Journal of Refrigeration, 2002, 25 (3), p. 351-361.

33. Walsh, P.,Leong, W. Effectiveness of several turbulence models in natural convection. International Journal of Numerical Methods for Heat \& Fluid Flow, 2004, 14 (5), p. 633-648.

34. Yang, T. CFD and field testing of a naturally ventilated full-scale building. University of Nottingham, 2004, p. 
35. Fumo, N.,Mago, P.,Luck, R. Methodology to estimate building energy consumption using EnergyPlus Benchmark Models. Energy and Buildings, 2010, 42 (12), p. 2331-2337.

36. Crawley, D. B.,Lawrie, L. K.,Winkelmann, F. C. et al. EnergyPlus: creating a new-generation building energy simulation program. Energy and Buildings, 2001, 33 (4), p. 319-331.

37. Eskin, N.,Türkmen, H. Analysis of annual heating and cooling energy requirements for office buildings in different climates in Turkey. Energy and Buildings, 2008, 40 (5), p. 763-773.

38. Guo, W.,Nutter, D. W. Setback and setup temperature analysis for a classic double-corridor classroom building. Energy and Buildings, 2010, $42(2)$, p. 189-197.

39. Henninger, R. H.,Witte, M. J.,Crawley, D. B. Analytical and comparative testing of EnergyPlus using IEA HVAC BESTEST E100E200 test suite. Energy and Buildings, 2004, 36 (8), p. 855-863.

40. Ng, L. C.,Musser, A.,Persily, A. K. et al. Multizone Airflow Models for Calculating Infiltration Rates in Commercial Reference Buildings. Energy and Buildings, 2012, 58 p. 11-18.

41. Sailor, D. J. A green roof model for building energy simulation programs. Energy and Buildings, 2008, 40 (8), p. 1466-1478.

42. Zhai, Z.,Johnson, M.-H.,Krarti, M. Assessment of natural and hybrid ventilation models in whole-building energy simulations. Energy and Buildings, 2011, 43 (9), p. 2251-2261.

43. Baharvand, M..Hamdan Ahmad, M.,Abdul Majid, R. et al. DesignBuilder Verification and Validation for Indoor Natural Ventilation. Journal of Basic and Applied Scientific Research (JBASR), 2013, 3 (4), p. 8.

44. Güneralp, B.,Seto, K. C. Environmental impacts of urban growth from an integrated dynamic perspective: A case study of Shenzhen, South China. Global Environmental Change, 2008, 18 (4), p. 720-735.

45. Tran, H.,Uchihama, D.,Ochi, S. et al. Assessment with satellite data of the urban heat island effects in Asian mega cities. International Journal of Applied Earth Observation and Geoinformation, 2006, 8 (1), p. 34-48.

46. Niewolt, S. Tropical climatology-an introduction to the climate of the low latitudes. John Willey \& Sons, London, 1977, p.

47. Takahashi, K.,Arakawa, H. Climates of southern and western Asia. Elsevier Science Ltd, 1981. p.

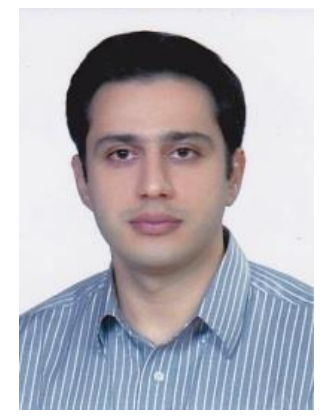

Mohammad Baharvand received his master from Azad University of khorasgan-Esfahan-Iran in 2006. He pursued his education as a $\mathrm{PhD}$ student of architecture in Universiti Teknologi Malaysia from 2011.

$\mathrm{He}$ was working as an architect in Espadana Consulting Engineers in Iran from 2004 until 2011. His PhD research focuses on double skin façade and natural ventilation. The followings are some his publications.

Baharvand, M., Ahmad, M. H. Safikhani, T., et al. Double Skin Façade Performance in Tropical Climate. In: 1st Asia Future Conference, Bangkok, Thailand, 2013.

Baharvand, M., Ahmad, M. H., Safikhani, T., et al. Thermal Comfort and Double Skin Facade in Hot and Humid Climate. In: Sustainability in Built Environment I. ISI Publications, Johor Bahru, 2012, vol. 1, p.113125 .

$\mathrm{He}$ is a research assistant at Institute Sultan Iskandar (ISI) and a member of Iranian Architecture society.

Email: baharvand12@gmail.com

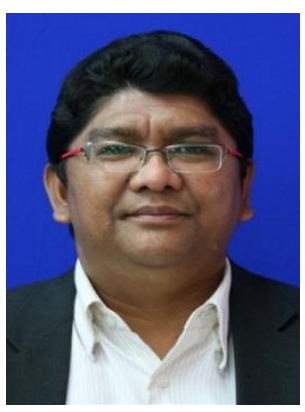

Mohd Hamdan Bin Ahmad received his B.A. from University of Miami, USA, in 1987 and his $\mathrm{PhD}$ from University of Manchester, UK, in 1997. He has taught from 1988 at Universiti Teknologi Malaysia where he is currently professor of architecture. His areas of interest are sustainable environmental architecture and building performance studies.

$\mathrm{He}$ is executive manager of Institute Sultan Iskandar (ISI). The followings are some of his publications.

Clement Oluwole, F., Ahmad, M., H., Parameters for building materials specifications in lagos, nigeria, $S A G E$ Open,2013. vol 3, no3

Lim, Y.,W., Zin Kandar, M, Ahmad, M.H., et al., Building façade design for daylighting quality in typical government office building, Building and Environment. 2012, vol 57, p.194-204.

$\mathrm{He}$ has been the panel of numerous international conferences. Also, he is a member of Lembaga Akreditasi Negara, Malaysian Structural Steel Association.

Email: b-hamdan@utm.my

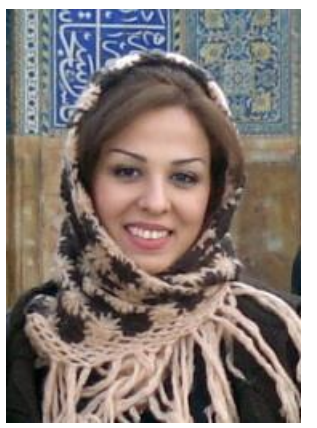

Tabassom Safikhani received her master from University of Art, Tehran, Iran, in 2009. She pursued her education as a $\mathrm{PhD}$ student of architecture in Universiti Teknologi Malaysia (UTM) from 2011. Her research field is greenery systems and vertical gardens.

She was working as an architect in Espadana Consulting Engineers in Iran from 2004 until 2006. Her PhD research focus is on vertical greenery systems. The followings are some her publications.

Safikhani, T., Megat Abdullah, A., Baharvand, M., et al., The Impact of Vertical Greenery Systems on Heat Reduction. In: 4th International Graduate Conference on Engineering Science \& Humanity 2013(IGCESH2013), Johor, Malaysia, 2013.

Safikhani, T., Megat Abdullah, A., Baharvand, M., et al. Green Roof Effects In Hot And Humid Climats. In: ITC 2012 Conference Proceeding, 2012.

Currently she is a teacher assistant in UTM.

Email: tabassomsafikhani@yahoo.com

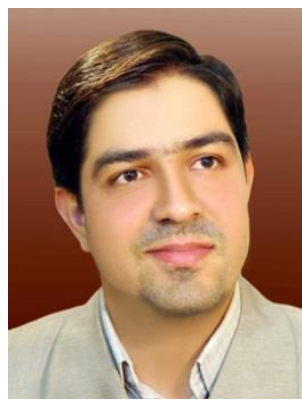

Sayyed Mohammad Mahdi Mirmomtaz received his master from Azad University of khorasgan-Esfahan-Iran in 2002. His areas of interest are Islamic architecture and Islamic urban planning.

He was working as an architect in Espadana Consulting Engineers in Esfahan-Iran from 2002 until 2005. He is a lecturer in Azad University and a member of Esfahan municipality. The followings are some his publications.

Mirmomtaz, S. M., Mahdaviyan, V., Sheykh Bahayi Role on Esfahan Urban Developing in Safavi Era. In: International Conference on the Development of Islamic Culture and Civilization, Esfahan, Iran, 2007.

Mirmomtaz, S. M., Mirheydari, Z., Methods of Using Nanotechnology in Hot and Dry Climates. In: National Conference on Desert Ecology, Tourism and Environmental Arts, Esfahan, Iran, 2012.

He has been the panel of conferences in Iran.. He is a member of Iranian Architecture society and Islamic engineering society.

Email: sm.mirmomtaz@gmail.com 